Ethiopian Journal of Environmental Studies \& Management 9 (1): 45 - 55, 2016.

ISSN:1998-0507

Submitted: August 13, 2015

doi: http://dx.doi.org/10.4314/ejesm.v9i1.5

Accepted: January 11, 2015

\title{
POVERTY AS A PRECURSOR FOR SPATIAL PATTERN OF WATERBORNE DISEASES PREVALENCE IN KWARA STATE, NIGERIA: A GEOGRAPHER'S VIEW
}

\author{
AKANBI, 0.A. \\ Department of Geography \& Environment Management University of Abuja, Gwagwalada, \\ Abuja, Nigeria \\ Email: geoakanbi2@yahoo.com
}

\begin{abstract}
This study aims at looking at the relationship between poverty and spatial pattern of waterborne diseases in Kwara State. The study involved 353 household heads across the three senatorial districts of the study area. Multi-stage sampling technique was adopted to obtain all the relevant data. In all, in-depth- interviews (IDI) were conducted and 664 questionnaires were also administered in the randomly selected settlements of the wards on the subject matter. Data from all these sources were subjected to correlation analysis, thus for Kwara North Senatorial district, the $p$-value of $.008<0.05$ level of significance stood at a correlation level of 0.530 at 22 df. Additionally, for Kwara Central Senatorial district, the $p$ value of $.352>0.05$ level of significance stood at a correlation level of 0.199 at $22 d f$, while for Kwara South Senatorial. This because the p-value of .194 >0.05 level of significance at a correlation level of 0.275 at $22 d f$. The study revealed that poverty has much influence on the prevalence of waterborne diseases: it therefore concludes that as a result of poverty, accessing adequate safe water facilities in the study area is a mirage. This is in addition to the neglect on the part of government in providing affordable water services, in the face of financial incapability of people of the study area. The study therefore recommends that, meaningful economic programmes be introduced in order to encourage sustainable income, through which poverty can be reduced.
\end{abstract}

Key Words: Poverty, Health Status, Waterborne Disease

\section{Introduction}

Accessibility to essentials of life is determined by the type of socio-economic activities. Thus, the types of socioeconomic activities a people are engaged in also determine their poverty and income level.

According to Merriam-Webster dictionary, poverty is a state of one who lacks a usual or socially acceptable amount of money or material possessions. To this end the duo of income and poverty are therefore central to explaining causes of waterborne diseases, because they both determine accessibility to essentials of life. Roth (2010) submitted that income is the gate way to wealth, through which man is able to eradicate his financial fortunes through which poverty can be reduced. Income also assists in full participation in societal activities (Marmot, 2002). Additionally, income can also lead to 
prolonged life expectancy; Kindig (2012) affirmed that people tend to live longer in high income countries than the low income countries.

However, because of inequality in incomes, not only in Nigeria, but in other parts of world, poverty has continued to ravage human society. Studies have shown that in Nigeria, people in the urban areas have higher income than the rural populace (Aigbokhan, 2000; Benzeval, Taylor and Judge, 2000 and Jideofor, 2012; Akanbi, 2014). This infers that there is more poverty in the rural areas than the urban areas and this manifested in economic deprivation, widespread diseases among others. World Bank, (2014) affirmed that, in Nigeria, poverty level remains at $33.1 \%$ and majority of people live on less than 2 dollars per day.

This poverty trend has been attributed to long-term ethnic conflicts and civil unrests, political instability corruption and poor rural development programmes by the government (Duffield, 2010). Such a situation makes accessibility to water and other important things difficult. Akanbi (2015) submitted that poverty is one of the major causes of prevalence of waterborne diseases. WHO (2014) has also linked poverty to malnutrition and inadequate water supply, as their availability can aggravate increase in diseases and deaths. WHO also opined that $80 \%$ of sicknesses in developing countries are associated to poor water.

The preponderance of waterborne diseases, which has led to many deaths, is an issue that worries the mind. The number of cases of waterborne diseases in Kwara State, like other developing countries is a matter of estimates. This is due to the sketchy nature of our data collection; many people do not attach importance to it. In an interview with a senior government of
Kwara State Ministry of Health (2015), the state recorded 500 cases of typhoid in 2009 , in 2010, there were 400 cases and in 2011 another 400 cases were recorded. Similarly, in 2012 the state recorded 600 cases of this disease and in 2013, 600 cases were reported while in 2014 over 700 cases were reported.

Therefore, the aim of this study is to look at the poverty as a precursor for spatial pattern of waterborne diseases and this aim is achieved through the following objectives: examine the sources of income, and evaluate it as one of the causes of waterborne diseases in Kwara State.

\section{Statement of Problem}

Poverty is one of the major determinants of health status of people, which by extension determines the socioeconomic status of a country. The United Nations (2015) affirmed that globally, about 1.2 billion people live in extreme poverty, while $46.0 \%$ of Nigerians live below poverty level with majority living on less than 2 dollars per day. Similarly, this same report, which covered the period 2004 and 2014, submitted that poverty rate in Kwara State stood at 23.7\%, which makes the state to fall within vulnerable poverty level. The present study therefore, examines the relationship between poverty and spatial pattern of waterborne diseases, using Kwara State, Nigeria as a case study.

\section{Null Hypothesis}

$\mathrm{H}_{0}$ : There is no significant relationship between poverty and spatial pattern of waterborne diseases in the senatorial districts of Kwara State.

\section{Study Area}

\section{Location and Size}

Kwara State is the gateway state between northern and southern Nigeria. It has a land area of 32,500 square kilometres. It is located between latitude $8^{\circ} 00^{\prime}$ and $9^{\circ} 10^{\prime}$ north and longitude $2^{\circ} 45^{\prime}$ 
and $6^{\circ} 40^{\prime}$ east. It is bounded in the north and east by River Niger, while it share boundary in the south with Oyo, Osun and Ekiti States. Similarly, Kwara State share boundary with Kogi State and Benin Republic in the east and west respectively (Oyebanji, 2000).

Kwara State has a population of 2,365,353 million people; this made up of 1,193,783 Males and 1,171,570 Females (Federal Government of Nigeria Official Gazette, 2007). Administratively, Kwara State is divided into sixteen (16) Local Government Areas (Figure 1). The Local Government Areas are further divided into 193 wards, and these also vary from one Local Government Area to another.

There are two main climate seasons, dry and wet seasons in Kwara State. The wet season commences between the end of March in the southern part and ends towards the end of October in all the parts of the State. The annual rainfall ranges from $1000 \mathrm{~mm}-1500 \mathrm{~mm}$ while the whole maximum average temperature ranges between $30^{\circ} \mathrm{C}-35^{\circ} \mathrm{C}$ (Oyebanji, 2000). Kwara State with its size has both highland and lowland. The landform consist of undulating hills, valleys and plains, the highest of which is found across the length and breadth of the state. The state is also drained by many rivers, chief among which is River Niger.

The vegetation is made up of rain forest and wooded savannah. The rain forest has trees like Iroko, Opepe and other trees are used in the construction industry.

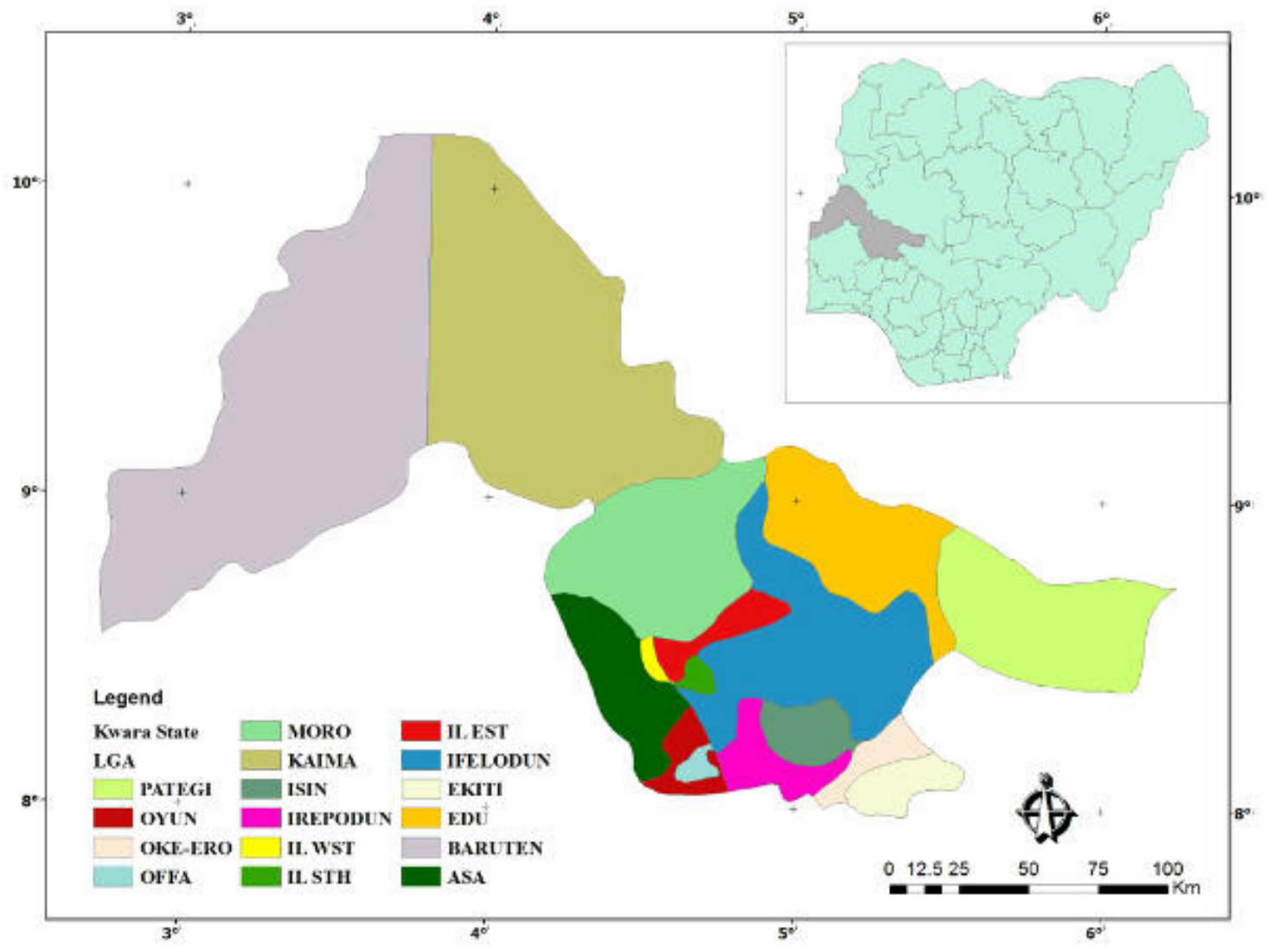

Figure 1: Kwara State Showing Local Government Areas Source: Modified from Ayanda and Shaaba (2001) 
Many dams and weirs are located in the state and they serve both state capital and other towns. (KWASEED, 2005). River Asa has been dammed to provide water for the residents of Ilorin. The Asa and Aagba dams are both located in Ilorin town with water capacity of 4 million and 2 million gallons per day respectively. Furthermore, river Moro has also been dammed, with water capacity of 60,000 gallon per day and it provides water for Army Barack, Shao and its environs.

In the Southern part of the state, River Oyun was dammed to provide water of about 20,000 gallon per day for the people of Offa and its environs (Kwara State Ministry of Water Resources, 2011). In all about twenty four dams and weirs are presently serving people of the state. There are also boreholes that are sited in all the nooks and crannies of state, but regrettably about $46 \%$ of these boreholes are non-functional (KWSPC,2006; Aganaba, 2006)

\section{Methodology}

The study adopted multi-stage sampling method. The study area was stratified into three on the bases of senatorial district-Kwara North, Kwara Central and Kwara South Senatorial Districts. The senatorial districts were later stratified into local government areas, districts and settlements. This is so, in order to ensure equal, accurate and adequate coverage of the study. Four stage sampling method is adopted in the selection of household. The first stage sampling involves picking two local government areas each randomly from the three senatorial districts (Table 1).

The second stage is the identification of settlements that make up the administrative districts in each local government area (Table 1). These administrative districts are germane to the sampling procedure, because they have remained unaltered over the years in Kwara State unlike the local government areas (LGAs). Suffice to add that, in identifying the settlements that make up the districts, the Nigeria 1991 population census data was utilized to determine the number of localities that make up the districts (Table 1). The Nigeria 1991 population census data is used, because it is disaggregated into localities.

The third stage in the sampling process involves, picking of $10.0 \%$ of all the settlements in each district, constituting the sampled settlements. The uniformity in the choice of $10.0 \%$ is as a result of variation in the number of settlements per administrative districts so as to ensure total coverage of the study area (Table 1).

The fourth stage is the selection of respondents in the settlements that make the study area. Household (HH) is group of people living together and maintaining unique eating arrangement (NBS, 2010). The respondents (Households) were estimated using National Population Commission (1991) estimated mean household for each settlement in Kwara State (as at 1991) put at 4.7.

A total of 664 questionnaires were administered on 353 households sampled across the three senatorial districts. Kwara South Senatorial district has the highest number of households of 127, while Kwara North and Central Senatorial districts have 118 and 108 respectively. The number of questionnaires administered in each senatorial district is also dependent on the number of estimated households (Table 1). The questionnaires were administered in the purposively sampled settlements with the help of trained field 45 research assistants. 
Table 1: Sampled households and Distribution of Questionnaire in the Study Area

\begin{tabular}{|c|c|c|c|c|c|}
\hline SENATORIAL & Districts & $\begin{array}{l}\text { Number of } \\
\text { Settlements }\end{array}$ & $\begin{array}{l}\text { Sampled } \\
\text { Settlements }(\mathrm{S} \\
\mathrm{S})\end{array}$ & $\begin{array}{l}\text { Estimated } \\
\text { Household= } \\
(\mathrm{SS} \times \text { Mean } \\
\mathrm{HH}\left(4.7^{*}\right) \\
\end{array}$ & $\begin{array}{l}\text { Number of } \\
\text { Questionnaire }\end{array}$ \\
\hline \multirow{7}{*}{$\begin{array}{l}\text { KWARA } \\
\text { NORTH }\end{array}$} & Oloru & 46 & 5 & 24 & 45 \\
\hline & Ejidongari & 30 & 3 & 14 & 27 \\
\hline & Lanwa & 85 & 9 & 42 & 79 \\
\hline & Ipaiye & 11 & 1 & 5 & 9 \\
\hline & Malete & 12 & 1 & 5 & 9 \\
\hline & Kaiama & 63 & 6 & 28 & 53 \\
\hline & Total & 247 & 25 & 118 & 222 \\
\hline \multirow{7}{*}{$\begin{array}{l}\text { KWARA } \\
\text { CENTRAL }\end{array}$} & Afon & 72 & 7 & 33 & 62 \\
\hline & Onire & 20 & 2 & 9 & 17 \\
\hline & Owode & 50 & 5 & 24 & 45 \\
\hline & Iponrin & 60 & 6 & 28 & 53 \\
\hline & Magaji-Are & 15 & 2 & 9 & 17 \\
\hline & Balogun/Gambari/Ibagun/Sango & 10 & 1 & 5 & 9 \\
\hline & Total & 227 & 23 & 108 & 203 \\
\hline \multirow{14}{*}{$\begin{array}{l}\text { KWARA } \\
\text { SOUTH }\end{array}$} & Share & 23 & 2 & 9 & 17 \\
\hline & Igbaja & 17 & 2 & 9 & 17 \\
\hline & Oke-Ode & 20 & 2 & 9 & 17 \\
\hline & Idofian & 11 & 1 & 5 & 9 \\
\hline & Omupo & 20 & 2 & 9 & 17 \\
\hline & Oro-Ago & 9 & 1 & 5 & 9 \\
\hline & Agunjin & 13 & 1 & 5 & 9 \\
\hline & Ora & 11 & 1 & 5 & 9 \\
\hline & Ile-Ere & 12 & 1 & 5 & 9 \\
\hline & Iloffa/Odo-Owa & 40 & 4 & 19 & 36 \\
\hline & Idofin & 40 & 4 & 19 & 36 \\
\hline & Ekan & 60 & 6 & 28 & 54 \\
\hline & Total & 276 & 27 & 127 & 239 \\
\hline & Grand Total & 750 & 75 & 353 & 664 \\
\hline
\end{tabular}

Source: National Population Commission (1991). (*Estimated mean of number of HH).

\section{Data Analysis}

Data presentation and analysis used in this study rely on both qualitative and quantitative approaches. For the presentation of results, descriptive methods such as tables, percentages and pictograms were used. Correlation analysis was also used to determine the relationship between poverty and spatial pattern of waterborne diseases in the senatorial districts of Kwara State.

This is of the form: $\mathrm{r}=$ $n \sum x y \sum x \sum y$ $\sqrt{\left(n \sum x^{2}-\left(\sum x\right)^{2}\left(n \sum y^{2}-\left(\sum y\right)^{2}\right)\right.}$
Decision rule: we reject $\mathrm{Ho}$ when the $\mathrm{P}$ value $<$ level of significance $(0.05)$

\section{Results and Discussion}

\section{Socio-Economic Characteristics of} Respondents

This part of the study explains the socioeconomic characteristics of the respondents in relation to sex, marital status, occupation, educational attainment, religion and income 
Table 2: Distribution of Respondents by Socio-Economic Characteristics

\begin{tabular}{lll}
\hline & Frequency & Percentage \\
\hline Sex & Male(213) & Male (60.2) \\
& Female(140) & Female(39.8) \\
Marital Status & Married(266) & Married (75.3) \\
& Spinster(87) & Spinster (24.7) \\
& Farming(117) & Farming (33.1) \\
& Business(53) & Business(15.0) \\
& Professional(48) & Professional(13.6) \\
& Artisan(64) & Artisan(18.1) \\
& Civil Service (50) & Civil Service (14.2) \\
& Unemployed(21) & Unemployed(6.0) \\
& Non-Formal(80) & Non-Formal(22.6) \\
Education & Primary(125) & Primary(35.4) \\
& Islamic(60) & Islamic(16.9) \\
& Secondary(27) & Tertiary(5.2) \\
& Tertiary(18) & None (12.3) \\
& None (43) & Christianity(43.7) \\
Religion & Christianity(154) & Muslim \\
& Muslim (130) & ATR \\
& ATR (69) & \\
Income & Less USD 25.2(138) & Less USD25.2 (39.2) \\
& USD 50.3-50.3(105) & USD 50.3-50.3 (29.8) \\
& USD 55.3-80.5(52) & USD 55.3-80.5 (14.8) \\
& USD85.5-110.7(21) & USD85.5-110.7 (6.0) \\
& USD115.7-140.8(26) & USD115.7-140.8 (7.4) \\
& More than USD 145.9(10) & More than N29,000(2.8) \\
& &
\end{tabular}

The profile of respondents in Table 2 shows that, $60.2 \%$ are male, while the remaining $39.8 \%$ are female. This may look reasonable in African society where discussions that have to do with family lay with household heads, who in most cases are men (Varga, 2001).

Furthermore, $75.3 \%$ of the respondents are married, while $24.7 \%$ are spinsters; the married are able to give detail knowledge of the subject matter. In the same vein, majority of the respondents are farmers. Farmers constitute $33.1 \%$ of the respondents, while $15.0 \%$ are business men and women. Furthermore 13.6.0\% of the respondents is professionals, while $18.1 \%$ are artisans and $14.2 \%$ are civil servants. Lastly $6.0 \%$ are unemployed: the others in this study include traders, artisans and unemployed. Suffice to say that $22.6 \%$ of the respondents have non-formal education, and $35.4 \%$ and $16.9 \%$ have primary and Islamic education.

Additionally, $7.5 \%$ and $5.2 \%$ of respondents have secondary and tertiary education. Lastly, $12.3 \%$ of the respondent does have a form any form of education. In the same vein $43.7 \%$ and $36.7 \%$ are Christians and Muslims respectively, while African Traditional Religion is $19.6 \%$. Furthermore, majority of respondents $(39.2 \%)$ in the study area earn less than USD 25.2 per month, while $29.8 \%$ earn between USD 25.2 and USD50.3. Suffice to add that, $14.8 \%$ of respondents earn between USD 55.3 and USD 80.5 and 6.0 
\% earn between USD 85.5 and USD110.7 monthly. Lastly, $7.4 \%$ and $2.9 \%$ of the respondents earn between USD115.7 and USD 140.8 and More than USD145.9 respectively.

The implication is that, availability of disposable income might be too meager and this may have negative implications for the socio-economic development of the area. Thus, it can be deduced that, income is one of the factors promoting waterborne diseases in the study area.

\section{Sources of Water in the Study Area}

Water is vital in socio-economic development of human society. The source of water available to a people can determine the quality of their lives. It is required for many purposes, thus its availability in quantity and quality is of importance to geographers.

For one, quality water to a large extent determines the productivity of a people. A healthy people are likely to be productive more than a sick society (Moe and Rheingans, 2006). However, accessibility to potable water in the study area is a mirage. A look at Figure 2, gives a sorry picture of sources of water in the study area.

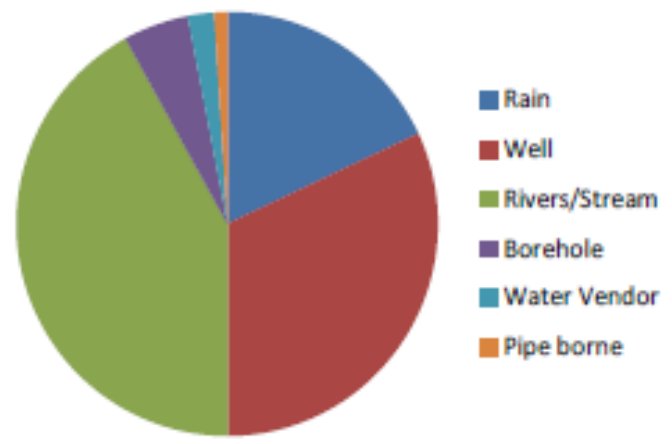

Figure 2: Sources of Water

According to the Figure 2, $18.0 \%$ of the respondents in the study area rely on rain water, especially during the rainy season. Similarly, $32.0 \%$ of respondents also rely on wells for their uses. Furthermore, majority of the respondents $(42.0 \%)$ in area take their water from rivers/streams and $5.0 \%$ source their water from bore holes. In the same vein $1.0 \%$ and $2.0 \%$ of the respondents also sources their water from pipe borne and water vendors respectively. This trend according to WHO (2015) is also a determinant of water -related diseases globally. In interviews with some opinion leaders across the length and breadth of the study area, they submitted that, most people source their water needs from wells, rivers/stream and lately from boreholes.

"The bulk of our water uses are sourced from rivers/streams; our women wake early in morning trek few kilometers to look for water. Beside the time this practice consumes, the method of conveying water home is not hygienic" (IDI, Idofin-Odo-Ase, Oke-EroLGA, 2014).

This view was also shared by a retired nurse:

"Water situation here is pathetic, as we source for water from unprotected sources. In most cases, water from wells (a major source of water) is hard.

Most rivers/streams recede with season, thus we are forced to live with unprotected water'" (IDI, Elemosho, Moro LGA, 2014).

In aligning with the above submissions, in an interview with another opinion leader, it was agreed that:

"We started getting relieved as a result of innovation of borehole technology and supply from water vendors. Prior to that period, we source our water from open surface water" (IDI, Lasoju, Asa LGA, 2014 ).

In summary, the picture of water supply in the study area shows that, larger 
percentage of the people of over $94.0 \%$ rely on unsafe sources for their water supply, while $66.0 \%$ source their water from questionable places( Figure 2). The implication of these may be negative not only for the study area, but for development of Nigeria. Rivers and streams are opened to pollution because they are not protected and as result of variation in season, rain water may not be available the year round. It follows therefore that people are forced to source their water from questionable sources.

Generally, the above scenario shows a poor state of water supply in the study area, as larger percentage of people in the study area relies on rivers and streams for their water. This may be as result of general absence of pipe borne water in the area, poverty level of the people, and level of ignorance among others. Accessibility to water in the study area varies from one area to another. In the sampled northern of part of the state (Moro, Kaiama), majority source their water from River Moseh and its consequents, rain and wells.

In the central part, the bulk of the people source their water from pipe borne, bore holes and water vendors. This may be as result of urban nature and concentration of few water facilities in the study area. Similarly, most people in the southern part of the study area also rely on water from rivers, wells and rain. Most wells in the study area do not meet safe water standard, as most of them are not covered (FGN, 2000). Thus besides being prone to incidence of pollution, much time and energy is spent sourcing water through wells.

One thing that worries the mind is that, the potable water supply situation in the study area falls short of expectation and national water standard. In the same vein, in some localities particularly in urban and peri-urban parts of the study area, many rely on water vendor. Therefore in overcoming the problem of waterborne diseases in Kwara State, constraints such as corruption, poverty which has made disposable income inadequate and ignorance are issues that must be tackled. Occupation of Respondents in the Study Area

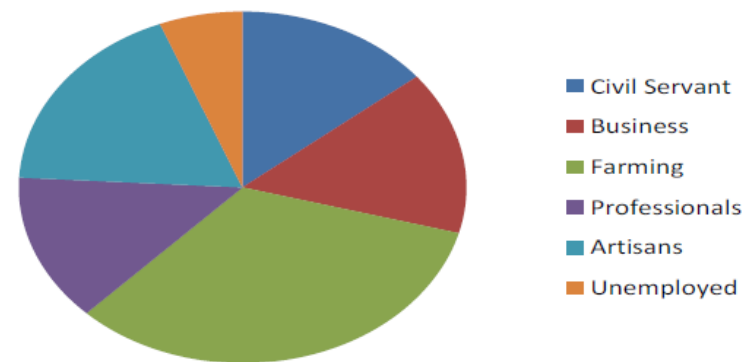

Figure 3: Distribution of Respondents by Occupation

Figure 3 reveals that $33.1 \%$ are predominantly peasant farmers, while, $15.0 \%$ business men and women respectively. The professionals and artisans (Carpenters, tailors, auto mechanic, driver, plumbers,) constitute $13.6 \%$ and $18.1 \%$ respectively, and $14.2 \%$ are civil servants, who are mostly teachers, nurses, among others. Unemployed constitute about $6.0 \%$, a fact corroborated by NBS (2010).

Table 3: The Result of Correlation Analysis on Poverty and Spatial Pattern of Waterborne Diseases in Kwara North senatorial District

\begin{tabular}{lll}
\hline & & $\begin{array}{l}\text { Prevalence and } \\
\text { occurrence of } \\
\text { WBDS }\end{array}$ \\
\hline Kwara North & Pearson Correlation & .530 \\
& Sig. (2-tailed) & .008 \\
& Df & 22 \\
\hline$* *$. Correlation is significant at the 0.01 level (2- \\
tailed)
\end{tabular}

The correlation co-efficient on Table 3 revealed that there is an average 
relationship between poverty and spatial pattern of waterborne diseases Kwara North Senatorial district. This is because the p-value of $.008<0.05$ level of significance at a correlation level of 0.530 at $22 \mathrm{df}$.

The null hypothesis which states that, "there is no significant relationship between poverty and spatial pattern of waterborne diseases in the senatorial districts of the study area" is being rejected. This is similar to the findings of Malik, Yasar, Tabinda and Abubakar (2012) of a rural community of Lahore, Pakistan where it was affirmed that, population poverty level is a determinant of waterborne diseases.

Table 4: The Result of Correlation Analysis on poverty and spatial pattern of Waterborne diseases in Kwara Central senatorial District

\begin{tabular}{lll}
\hline Kwara Central & Pearson Correlation & .199 \\
\cline { 2 - 3 } & Sig. (2-tailed) & .352 \\
& Df & 22 \\
\hline
\end{tabular}

The correlation co-efficient on Table 4 revealed that there is a weak relationship between poverty and spatial pattern of waterborne diseases at Kwara Central Senatorial district. This because the pvalue of $.352>0.05$ level of significance at a correlation level of 0.199 at $22 \mathrm{df}$.

The null hypothesis that states that, "there is no relationship between poverty and spatial pattern of waterborne diseases in the senatorial district of the study area" is being accepted. This may be associated to the fact that, most social facilities in the state are concentrated in this senatorial district because it houses both state capital as well as the commercial hub of the state (Akanbi, 2015).
Table 5: The Result of Correlation Analysis on Poverty and spatial pattern of waterborne diseases in Kwara South senatorial district

\begin{tabular}{lll}
\hline Kwara South & Pearson Correlation & .275 \\
\cline { 2 - 3 } & Sig. (2-tailed) & .194 \\
& $\mathrm{~N}$ & 24 \\
\hline
\end{tabular}

The correlation co-efficient on Table 5 revealed that there is a weak relationship between poverty and spatial pattern of waterborne diseases in Kwara South Senatorial. This because the p-value of $.194>0.05$ level of significance at a correlation level of 0.275 at $22 \mathrm{df}$.

The null hypothesis that states that, "there is no relationship between poverty and spatial pattern of waterborne diseases in the senatorial districts of the study area" is being accepted.

Kwara South Senatorial district is noted for its self-help project in the face of government apathy. This suggests that the prevalence of water borne diseases is more pronounced in Kwara North senatorial district than the other two senatorial districts of Kwara Central and South senatorial districts. This scenario may be associated with the fact, Kwara South Senatorial district is known for their self help projects in the provision of social amenities. This according to Toyobo et al. (2014) has helped to uncover practical development and modified decision to be made, in order to overcome community problems.

\section{Conclusion and Recommendations}

The need for safe water is central to the development of the human society because of its multifaceted roles. However, accessibility to potable water is determined by income. This study reveals that poverty pervades the study area. 
Poverty as a Precursor for Spatial Pattern of Waterborne Diseases................AKANBI, O.A.

Bearing in mind the relationship between poverty and water, people are forced to source their water needs through various means. The study therefore concludes that, waterborne diseases are common in the study area as a result of dearth of potable water: accessing the alternative is difficult occasioned by poverty level in the area. This paper therefore recommends that, relevant economic programmes be introduced in bid to arouse economic activities through which disposable income can be achieved. The advantage of this is that, poverty can be reduced and standard of living can be improved on. Governments should as a matter of urgency priorities provision of potable water, so that people can be saved from agonies of waterborne diseases.

\section{References}

Aganaba, D.A. (2006). Report of GIS Data/Mapping in Kwara State to UNICEF Assisted Water and Sanitation Agency. : 45 - 70

Aigbokhan, B.E. (2000). Poverty, Growth, and Inequality in Nigeria. Retrieved on $8 / 10 / 2015$ from www.unpan1.un.org.

Akanbi O.A. (2014). Spatial Pattern of Public Health Facilities and its Implications on the Rural People of Kuje Area Council, Abuja, Nigeria. Geo. Studies Forum

Akanbi, O.A. (2015). Spatio-Temporal Analysis of Waterborne Diseases in Kwara State, Nigeria. An Unpublished Ph.D, Ahmadu Bello University, Zaria, Nigeria.

Ayanda, J. and Shaaba, A. (2001). Compendium of Local Government in Kwara State, 2nd Edition, Ilorin, Jomas.

Benzeval, M., Taylor, J. and Judge, K. (2000). Evidence on the Relationship
Between Low Income and Poor Health: I s Government Doing Enough. Fiscal Studies, 21(3): 375399.

Duffield, C. (2010). The Illegal but Lucrative Trade in Educational Materials. Retrieved on 8/10/2015 from www.Bbc.co.uk

Federal Republic of Nigeria (2000) National Water Supply and Sanitation Interim Strategy

Note, 2000. FGN, Nov; 2000, Retrieved on 23/4/201 www.siteresources.worldbank.org

Federal Republic of Nigeria (2007). Official Gazette, Lagos-Nigeria., 24(94).

Jideofor, A. (2012). Poverty Alleviation in Nigeria: Which Way Nigeria? Retrieved on 8/10/2015 from Holler Africa

Kindig, D.A. (2012). The Link Between Income and Health. Retrieved on 8/10/2015 from www.improvingpopulationhealth.org /blog

Kwara State Ministry of Health (2014). Unpublished Health Data. Kwara State Ministry of Health, Ilorin, Nigeria.

Kwara State Planning Commission (2006). Kwara State Economic Empowerment and Development Strategy.

Malik, A., Yasar, A., Tabinda, A.B. and Abubakar, M. (2012). Waterborne Diseases, Costs of Illness and Willingness to Pay for Diseases Intervention in Rural Communities of Developing Countries. Iran J. of Public Health, 41(6): 39-49

Marmot, M. (2002). The Influence of Income on Health: Views of an Epidemiologist. Health Aff March, 21(2): 231-46 
Merriam-Webster Dictionary. Retrieved on $8 / 12 / 2015$ from beta-merriamwebster.com/dictionary/poverty

Moe, C.L. and Rheingans, R.D. (2006). Global Challenges in Water, Sanitation and Health. Journal of Water and Health, (04 Suppl) :41-55.

Oyebanji, J.O. (2000). Kwara State. In: Mamman, A.B., Oyebanji, J.O. and Peters, S.W. (eds) A people United, A Future Assured, Gabumo, Calabar, Nigeria: 293 - 294.

Roth, D.J. (2010). Why Your Income Is So Important. Retrieved on 08/10/2015 from www.getrichslowly.org

Toyobo, A.E., Amao, F.L. and Ajala, C.O. (2014). Self-Help As a Panacea for Rural

Infrastructural Provision in Kaiama Local Government Area, Kwara State , Nigeria . Developing Country Studies, 4(23): 113-122

United Nations Organization (2015). Global Multi-Dimensional Poverty Index. Retrieved on 21/11/2015 from dataforall.org/dashboard/ophi/index.p hp/

Varga, C.A. (2001). The Forgotten Fifty Percentage: Review of Sexual and Reproductive Health

Research and Programmes focused on Boys and Young Men in SubSaharan Africa. African Journal of Reproductive Health, 3(1):74-195.

World Bank (2014) Nigeria Country Brief. Retrieved on 11/10/2015 from www.worldbank.org

World Health Organization (2014). Water Related Diseases. Retrieved on 10/9/2015 from www.who.int/watersanitationhealth/disease/malnutrition.

World Health Organization (2015) .Water -Related Diseases. Retrieved on 11/10/2015 from www.who.int/water-relatedsanitation-health/diseases/en 